Sains Malaysiana 50(7)(2021): 1997-2006

http://doi.org/10.17576/jsm-2021-5007-14

\title{
The Effect of Type, Duration and Intensity of Exercise on Inflammatory Markers CRP, IL-6 and IL-18 in Metabolic Syndrome Patients: A Systematic Review
}

(Kesan Jenis, Tempoh dan Keamatan Senaman terhadap Penanda Radang CRP, IL-6 dan IL-18 pada Pesakit Sindrom

Metabolik: Suatu Tinjauan Sistematik)

Srijit Das, Isa Naina-Mohamed, Mohamed S Zulfarina, Hazwan Hazrin Salim, AzWani Zawawi, Tarrsini Thevaraj, Ku Nurmahirah Ku-Ahmad-Nasir, Dennis Kheng Zhou \& SeOng Lin TeOH*

\section{ABSTRACT}

Metabolic syndrome (MetS) has become a major clinical challenge worldwide due to rise of urbanisation, surplus energy intake, increasing obesity and sedentary lifestyle. C-reactive protein (CRP), interleukin-6 (IL-6) and interleukin-18 (IL-18) are associated with MetS. We performed a systematic review to investigate the effects of exercise on these markers in MetS patients and therefore to determine the best exercise regime for them. We searched Medline (Pubmed and Ovid), Scopus and CINAHL databases. The searches were standardized by using the same search strategy which included the terms such as 'metabolic syndrome', 'CRP', 'IL-6', 'IL-18' and 'exercise'. Only clinical human studies published from Jan 2007 to May 2018 were included. A total of 11 clinical trials (466 participants) were selected. Majority of the studies were randomized controlled studies (90.9\%). All studies showed a decrease in serum levels of the biomarkers. However, not all were statistically significant. The main type of exercise in most of the studies was aerobic. Aerobic-resistance exercise was more effective rather than aerobic alone, but aerobic exercise was the only effective as a sole intervention. Aerobic exercise showed promising role as the main lifestyle intervention in MetS. It is concluded that patients with Met $\mathrm{S}$ should have combined aerobic-resistance exercise.

Keywords: c-reactive protein; exercise; IL-6; IL-18; metabolic syndrome

\section{ABSTRAK}

Sindrom metabolik (MetS) telah menjadi cabaran klinikal utama di seluruh dunia akibat kemajuan perbandaran, pengambilan tenaga yang berlebihan, peningkatan kadar obesiti dan gaya hidup yang tidak aktif. Penanda seperti protein C-reaktif (CRP), interleukin-6 (IL-6) dan interleukin-18 (IL-18) telah dikaitkan dengan MetS. Kami menjalankan ulasan sistematik untuk mengkaji kesan senaman kepada penanda ini pada pesakit MetS dan juga untuk mengetahui rejim senaman yang terbaik untuk mereka. Carian telah dijalankan melalui pangkalan data Medline (Pubmed dan Ovid), Scopus dan CINAHL. Carian telah diseragamkan dengan menggunakan strategi pencarian yang sama termasuk istilah seperti 'sindrom metabolik', 'CRP', 'IL-6', 'IL-18'dan 'senaman'. Hanya kajian klinikal yang diterbitkan dari Jan 2007 hingga Mei 2018 termasuk dalam kajian ini. Sebanyak 11 kajian klinikal (466 peserta) telah dipilih. Majoriti kajian adalah kajian terkawal rawak (90.9\%). Semua kajian menunjukkan penurunan kadar penanda dalam serum. Walau bagaimanapun, tidak semuanya menunjukkan perbezaan yang signifikan. Jenis utama senaman dalam kajian terlibat adalah senaman aerobik. Senaman rintangan-aerobik adalah lebih berkesan berbanding senaman aerobik, tetapi hanya senaman aerobik merupakan intervensi yang berkesan jika dilakukan secara tunggal. Senaman aerobik berpotensi dijadikan intervensi gaya hidup utama dalam MetS. Disimpulkan bahawa pesakit MetS memerlukan gabungan senaman rintangan-aerobik.

Kata kunci: IL-6; IL-18; senaman; sindrom metabolik; protein c-reaktif 


\section{INTRODUCTION}

Metabolic syndrome (MetS) is a condition in which there is a clustering of several different metabolic abnormalities i.e. hyperglycaemia, hypertension, dyslipidaemia, and central obesity. Worldwide prevalence of MetS ranges from $<10$ to $84 \%$, depending on the geographical region, urban or rural environment and composition (sex, age, race, and ethnicity) of the population studied. Higher socioeconomic status, sedentary lifestyle, and high body mass index (BMI) were significantly associated with MetS. This situation shows the need for an improvement on the need for better management in reducing the mortality and morbidity caused by MetS. Its prevalence is increasing worldwide, and the prevalence in the adult population is estimated to be around 20-25\% (Moreira et al. 2014). In Malaysia, the prevalence of MetS was reported to be $16.5 \%$ (Zainuddin et al. 2011).

Over the past decades, several definitions of MetS have been proposed by different organizations. There are three major definitions that can be considered i.e. the definition of the World Health Organization (WHO), issued in 1998 (Takamiya et al. 2004); the definition of the National Cholesterol Education Program (NCEP) Adult Treatment Panel (ATP) III, issued in 2001 and updated in 2004 and 2005 (Expert Panel on D 2001); and the definition of the International Diabetes Federation (IDF), introduced in 2005 (Alberti et al. 2005). These three definitions agree that the core criteria of MetS include: blood glucose impairment (hyperglycemia and/or insulin resistance), excess abdominal/body fat (increased waist and/or obesity), dyslipidemia (low HDL-cholesterol and/ or high triglycerides), and elevated blood pressure. It is not a mandatory for a person to have all the characteristics. However, with the presence of one character, it predisposes an individual to have others, as well. Table 1 summarized the criteria for diagnosis of MetS.

TABLE 1. Criteria for the diagnosis of MetS

\begin{tabular}{|c|c|c|c|c|}
\hline Organization & WHO & EGIR & NCEP & IDF \\
\hline Criteria & $\begin{array}{l}\text { Presence of ONE of } \\
\text { the following: } \\
\text { - Diabetes mellitus } \\
\text { - Impaired glucose } \\
\text { tolerance } \\
\text { - Impaired fasting } \\
\text { glucose } \\
\text { - Insulin resistance } \\
\text { AND two of the } \\
\text { following: } \\
\text { - BP } \geq 140 / 90 \\
\text { mmHg } \\
\text { - Dyslipidemia } \\
\text { - Central obesity } \\
\text { - Microalbuminuria } \\
\left({ }^{(3)}\right.\end{array}$ & $\begin{array}{l}\text { Insulin resistance AND } \\
\text { two or more of the } \\
\text { following: } \\
\text { - Central obesity }{ }^{(4)} \\
\text { - Dyslipidemia }{ }^{(5)} \\
\text { - } \mathrm{BP} \geq 140 / 90 \mathrm{mmHg} \\
\text { - } \mathrm{FBG} \geq 6.1 \mathrm{mmol} / \mathrm{L}(110 \\
\mathrm{mg} / \mathrm{dL})\end{array}$ & $\begin{array}{l}\text { Presence of three of the } \\
\text { following ( } 2001 \text { criteria): } \\
\text { - Central obesity }{ }^{(6)} \\
\text { - Dyslipidemia } \\
\text { - } \mathrm{BP} \geq 130 / 85 \mathrm{mmHg} \\
\text { - FBG } \geq 6.1 \mathrm{mmol} / \mathrm{L}(110 \\
\mathrm{mg} / \mathrm{dL}) \\
\\
\text { Update (2004) } \\
\text { - Elevated waist } \\
\text { circumferences }^{(8)} \\
\text { - Elevated triglycerides } \\
\text { - Reduced high density } \\
\text { lipoproteins }{ }^{(10)} \\
\text { - Elevated BP }{ }^{(11)} \\
\text { - Elevated fasting } \\
\text { glucose }^{(12)}\end{array}$ & $\begin{array}{l}\text { Central obesity }{ }^{(13)} \\
\text { AND any two of the } \\
\text { following } \\
\text { - Raised triglycerides } \\
\text { - Reduced high density } \\
\text { lipoproteins }{ }^{(15)} \\
\text { - Elevated BP }{ }^{(16)} \\
\text { - Elevated fasting } \\
\text { blood glucose }^{(17)}\end{array}$ \\
\hline
\end{tabular}

WHO: World Health Organization, EGIR: European Group for the Study of Insulin Resistance, IDF: International Diabetes Federation, NCEP: US National Cholesterol Education Program, BP: blood pressure, FBG: Fasting blood glucose

(1) $\mathrm{TG} \geq 1.695 \mathrm{mmol} / \mathrm{L}$ and $\mathrm{HDL} \leq 0.9 \mathrm{mmol} / \mathrm{L}$ (male), $\leq 1.0 \mathrm{mmol} / \mathrm{L}$ (female)

(2) Waist/hip ratio $>0.90$ (male), $>0.85$ (female), or body mass index $>30 \mathrm{~kg} / \mathrm{m}^{2}$

(3) Urinary albumin excretion ratio $\geq 20 \mathrm{mcg} / \mathrm{min}$ or albumin/creatinine ratio $\geq 30 \mathrm{mg} / \mathrm{g}$

(4) Waist circumference $>94 \mathrm{~cm}$ (male), $>80 \mathrm{~cm}$ (female)

(5) $\mathrm{TG} \geq 2.0 \mathrm{mmol} / \mathrm{L}$ and $/$ or $\mathrm{HDL}<1.0 \mathrm{mmol} / \mathrm{L}$ or treated for dyslipidemia

(6) Waist circumference $\geq 102 \mathrm{~cm}$ or 40 inches (male), $\geq 88 \mathrm{~cm}$ or 36 inches (female)

(7) $\mathrm{TG}>1.7 \mathrm{mmol} / \mathrm{L}(150 \mathrm{mg} / \mathrm{dL}$ ) and $\mathrm{HDL}<40 \mathrm{mg} / \mathrm{dL}$ (male), $<50 \mathrm{mg} / \mathrm{dL}$ (female)

(8) $>40$ inches or $102 \mathrm{~cm}$ (male), $>35$ inches or $88 \mathrm{~cm}$ (female)

(9) $\geq 150 \mathrm{mg} / \mathrm{dL}(1.7 \mathrm{mmol} / \mathrm{L})$

$(10)<40 \mathrm{mg} / \mathrm{dL}$ or $1.03 \mathrm{mmol} / \mathrm{L}$ (male), $<50 \mathrm{mg} / \mathrm{dL}$ or $1.29 \mathrm{mmol} / \mathrm{L}$ (female)

(11) $\geq 130 / 85 \mathrm{mmHg}$ or medicated for hypertension

$(12) \geq 100 \mathrm{mg} / \mathrm{dL}(5.6 \mathrm{mmol} / \mathrm{L})$ or medicated for hyperglycemia

(13) Waist circumference with ethnicity specific values (if BMI is $>30 \mathrm{~kg} / \mathrm{m}^{2}$, central obesity can be assumed and waist circumference need not be measured

(14) $\mathrm{TG}>150 \mathrm{mg} / \mathrm{dL}(1.7 \mathrm{mmol} / \mathrm{L})$ or medicated for hyperlipidemia

(15) $\mathrm{HDL}<40 \mathrm{mg} / \mathrm{dL}(1.03 \mathrm{mmol} / \mathrm{L})$ in males, $<50 \mathrm{mg} / \mathrm{dL}(1.29 \mathrm{mmol} / \mathrm{L})$ in females or medicated for this lipid abnormality

(16) Systolic $\mathrm{BP}>130$ or diastolic $\mathrm{Bp}>85 \mathrm{mmHg}$, or medicated for previously diagnosed hypertension

(17) $\mathrm{FBG}>100 \mathrm{mg} / \mathrm{dL}(5.6 \mathrm{mmol} / \mathrm{L})$ or previously diagnosed type 2 diabetes 
There are many reports on the role of physical activity in managing MetS. Many researchers throughout the world have been focusing on the effect of the physical activity in MetS with regard to its action on laboratory parameters in the form of clinical studies. In a study by Woods et al. (2012), the authors concluded that regular exercise does indeed reduce systemic inflammation. They postulated that these effects are derived from the reduction of adipose tissue, adipose tissue being well-known to contribute to systemic inflammation by producing proinflammatory cytokines (Fried et al. 1998). Other fat-loss independent mechanisms were also suggested such as the paradoxical role of interleukin (IL)-6 production during exercise on reducing long term inflammation, reduction of oxidative stress and acting on a pathway known as the cholinergic anti-inflammatory pathway.

The Insulin Resistance Atherosclerosis Study (IRAS) in the year 2000, stated that stimuli such as overnutrition would result in cytokine hypersecretion, mainly interleukin IL-1, IL-6, and tumour necrosis factor (TNF) alpha and eventually lead to insulin resistance and diabetes in genetically or metabolically predisposed individuals (Festa et al. 2000). These cytokines also exert major stimulatory effect on the hepatic synthesis of acute-phase proteins.

A review published by Kaur (2014) concluded that elevated levels of C-reactive protein (CRP) are associated with an increased waist circumference (WC), insulin resistance, BMI, and hyperglycaemia and are increased with the number of the MetS components. It is more likely to be elevated in obese insulin-resistant, but not in obese insulin-sensitive subjects. In addition, it has been demonstrated that regardless of the presence or degree of the MetS in an individual, CRP levels independently predicted the occurrence of future cardiovascular disease (CVD) events. Because of the simple reason that MetS was linked with a greater chance of future CVD events, CRP level may be an important independent predictor of unfavourable outcomes in the MetS (Rutter et al. 2004).

IL- 6 is released by many types of cells in the body such as adipocytes and muscle cells as well as immune T-cells and macrophages. As a cytokine, it acts to promote inflammation and as a myokine, it commands potent anti-inflammatory action (Pedersen \& Fischer 2007). This accounts, in part, for the anti-inflammatory effect exercise has. As a cytokine, (IL)-6 receptors expressed in the hypothalamus allow in to control body temperature, appetite, and energy intake. High serum levels such as in obesity are also linked to insulin resistance (Kim et al. 2009) and its production by adipocytes accounts for the high levels of CRP in obese individuals (Bastard et al. 1999). IL-18 was reported to be associated insulin resistance (Fischer et al. 2005; Straczkowski et al. 2007; Van Guilder et al. 2006). According to a study by Straczkowski et al. (2007), it was speculated that IL-18 may be the factor inhibiting adiponectin secretion, which has anti-inflammatory properties, thereby contributing to hypoadiponectinemia in obesity.

It is clear that inflammation plays a key role in the pathogenesis of MetS. Therefore, the use of such inflammatory markers could serve as a biochemical panel to risk stratify as well as monitor the treatment of MetS. A study by Srikanthan et al. (2016) concluded that inflammatory biomarkers correlate significantly to MetS and could be used for early diagnosis as well as to monitor the efficacy of treatment. Regarding the treatment for MetS, it would include lifestyle changes, more specifically, exercise. CRP, IL-6 and IL-18 are associated with MetS. Our main objective for this systematic review was to investigate the effects of exercise on CRP, IL-6 and IL-18 biochemical markers associated with MetS and to look into the effects of different types, duration and intensity of exercises on the level of said biochemical markers..

\section{MATERIALS AND METHODS}

\section{DATA SOURCES AND SEARCH STRATEGY}

Prior ethical approval was obtained from the institution ethics committee. This systematic review was done following the preferred reporting items for systematic review and meta-analyses (PRISMA) guidelines (Figure 1). Studies were identified through MEDLINE (Pubmed and Ovid), CINAHL and Scopus. The databases were searched for articles published from year 2007 until May 2018. Searches were limited to randomized or controlled trials in humans. Only articles published in English language were included. Using the standard PICO model; population, intervention, comparison and outcome, the following systematic review was planned appropriately. The search used a mixture of different related keywords and subject terms for each part of the review question. The truncation and Boolean operator 'OR' were used to expand the search while the Boolean operator 'AND' applied to combine the parts of the review question. The following search terms were included: (exercise OR physical activity*) AND (CRP OR c-reactive protein OR interleukin-6 OR IL-6 OR interleukin-18 OR IL-18) AND (metabolic syndrome* OR syndrome x OR hypertriglyceridemia* waist OR insulin resistance syndrome* OR obesity syndrome* OR dysmetabolic syndrome*). The search strategy was depicted in Table 2. 


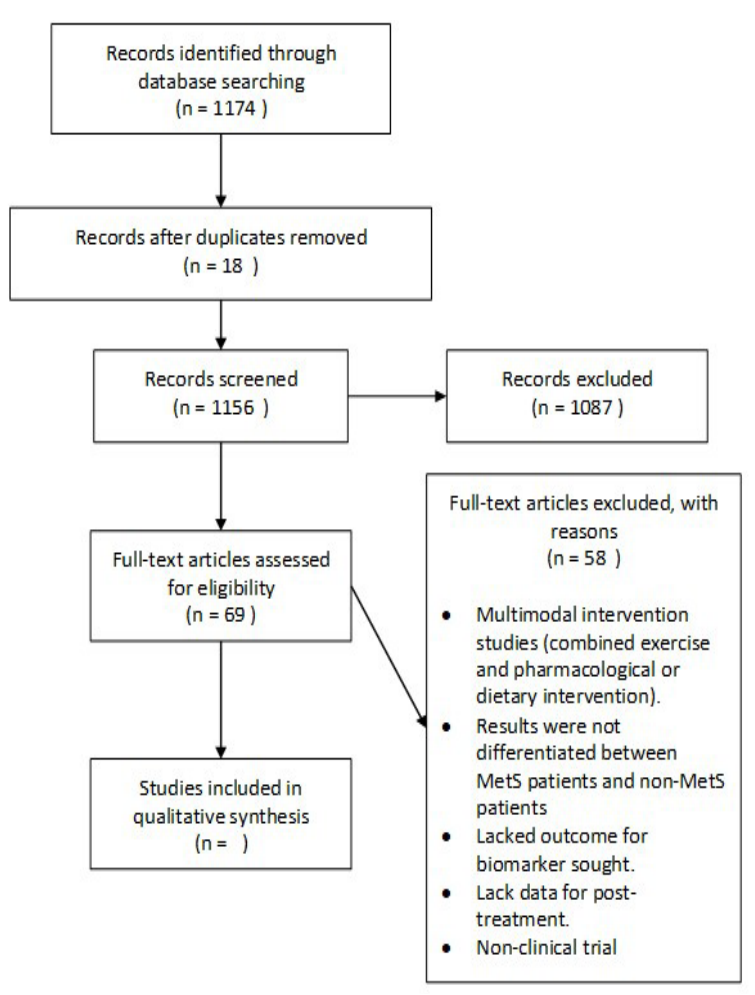

FIGURE 1. PRISMA Chart

TABLE 2. Search strategy

\begin{tabular}{cc}
\hline No. & Criteria \\
\hline 1. & Exercise* \\
2. & Physical activit* \\
3. & CRP \\
4. & C-reactive protein \\
5. & Interleukin 6 \\
6. & Interleukin-6 \\
7. & IL-6 \\
8. & IL 6 \\
9. & Interleukin 18 \\
10. & Interleukin-18 \\
11. & IL-18 \\
12. & IL 18 \\
13. & Metabolic syndrom* \\
14. & Syndrome x \\
15. & Hypertriglyceridemi* waist \\
16. & Insulin resistance syndrome* \\
17. & Obesity syndrom* \\
18. & Dysmetabolic syndrom* \\
19. & 1 or 2 \\
20. & or 15 or 16 or 17 or 18 or 19 \\
21. & 20 and 21 and 22 \\
22. & \\
23. & or 6 or 7 or 8 or 9 or 10 or 11 or 12 or 13 \\
\hline & or 4 or \\
\hline 1 &
\end{tabular}




\section{STUDY SELECTION}

Literature search was conducted by two independent authors randomly assigned to each article from a pool of six authors (MSZ, HHS, AZ, TT, KKAN, DKZ). Articles were only accepted if both reviewers agreed that the article was of relevance and of high quality. Any disagreement regarding the selection of studies were resolved by consensus. If necessary, a third researcher (SD, SLT and INM) was consulted. Reasons for inclusion and exclusion of each of the article were recorded.

\section{INCLUSION CRITERIA}

Using the standard PICO model; population, intervention, comparison and outcome, studies were considered to be eligible for inclusion according to the following criteria: participants with MetS aged $\geq 18$ years; randomized or non-randomized (quasi) controlled trials with at least two groups, either control and intervention groups or more 2 interventions; exercise: aerobic, anaerobic, resistance/ strength, combination of aerobic and resistance exercise and no exercise (sedentary); and study examined at least one of the following inflammatory markers CRP, IL-6 or IL-8.

\section{EXCLUSION CRITERIA}

Study focused on children, adolescents, and young adults $\leq 18$ years of age were excluded; study with a dietary co- intervention; letter, case report, case study, review, casecontrol study, intervention without a comparison group and cohort study; and articles written in languages other than English were excluded.

\section{DATA EXTRACTION}

Paired reviewers extracted the following information for each study. The data extracted from the results included; the first author name, publication year, country, study design, gender, sample size, intervention (type, frequency, intensity, duration per-session, study duration, and treatment effect (comparisons between intervention and control or between multiple intervention groups).

\section{RESULTS}

\section{STUDY SELECTION}

The algorithm for selection of studies in this systematic review was shown in Figure 2. A total of 1174 articles related to exercise and MetS were obtained through searching 4 databases; 281 from Pubmed, 210 from MEDLINE via Ovid, 458 from Scopus and 225 from CINAHL. These included systematic reviews, case reports, cohort studies, cross-sectional studies and randomized controlled trials (RCTs). From this number, a total of 1163 studies were excluded from this study by applying our exclusion criteria as well as by eliminating the duplicated studies.

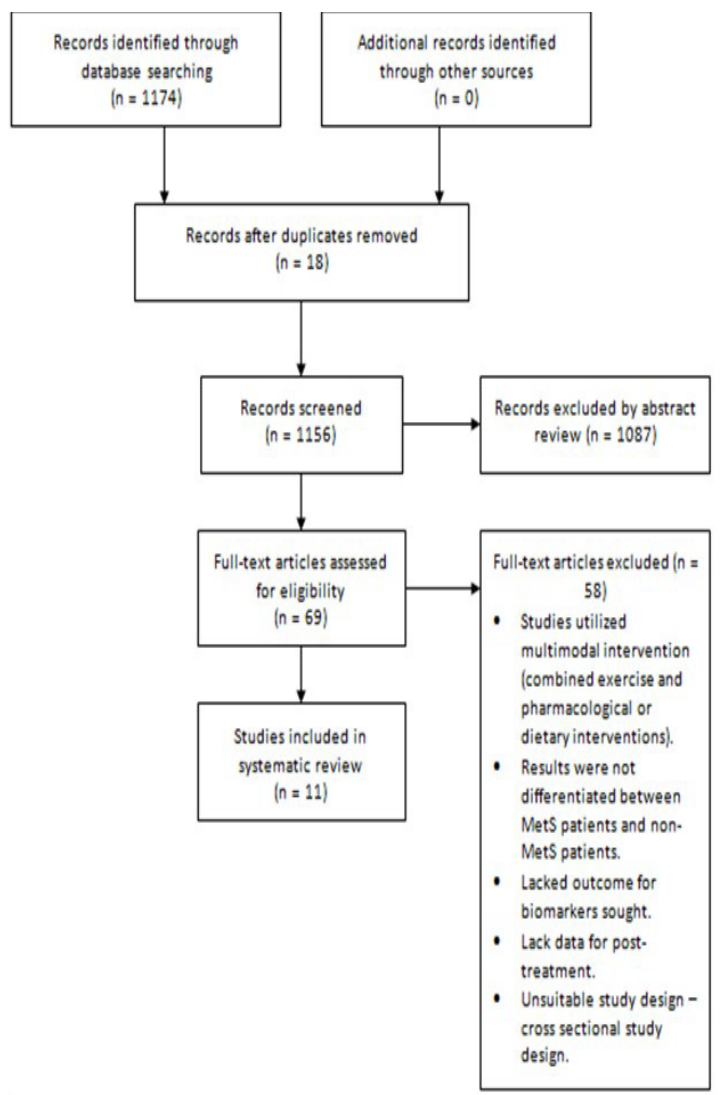

FIGURE 2. The algorithm for selection of studies in this systematic review 


\section{RANGE AND CHARACTERISTICS OF SELECTED STUDIES}

Eventually, a total of 11 studies were selected for the systematic review. Of the total 11 studies, 10 of them were (RCTs), with randomized controlled trials (RCTs), with the remaining study being a quasi-experimental study design. The study range was from 9-176 participants, the total being 466 individuals with their age ranging from 18-75 years. Of these 466 participants, 258 participants were females $(55.36 \%)$ and 208 participants were males (44.64\%). All participants involved were patients who had MetS as defined by various bodies such as the NCEP ATP-III, IDF, and WHO criteria. The exercise programs in the studies selected consisted of aerobic exercise, resistance exercise and combined aerobic-resistance exercise. Regarding to the setting of the exercise program, 10 of the studies had supervised exercise programs with 1 study being an unsupervised home-based intervention. Intensity of the exercise was objectively measured in many studies using different parameters which includes; percentage of maximum heart rate (MHR), percentage of heart rate reserve (HRR), percentage of maximum oxygen consumption $\left(\mathrm{VO}_{2} \max \right)$ and percentage of 1 repetition maximum (1RM). The duration of these each session ranged from 20-60 min. The average period of trials was around 20 weeks, ranging from 2 weeks to 1 year. These studies were collected from the United States of America (USA), Italy, Germany, Norway, Brazil and Taiwan. The majority of the participants involved were from Italy, followed by USA.

\section{RESULTS OF SYSTEMATIC REVIEW}

Adipose tissue is a major endocrine organ which secretes many important factors including a group of cytokines known as adipokines. Any condition which confers an expansion of this adipose tissue in the human body is likely to lead to adverse consequences and MetS is one such entity. Currently on the rise worldwide, MetS increases morbidity and mortality by adversely affecting the cardiovascular functions. Exercise is considered as one of the key tenets in managing this condition and the level of adipokines can be used to monitor response to differing types of exercises. The biomarkers chosen were IL-6, IL-18 and CRP as they frequently featured prominently in majority of the studies.

As expected, all studies showed a decrease in serum levels of the biomarkers stated. However, not all were statistically significant. The type of exercise showed an influence on the biomarkers. The main type of exercise done in majority of the studies in our review was of aerobic type. Aerobic exercises can take many forms and includes jogging, walking, dancing, and treadmill exercises. The other type of exercise is resistance exercise, which as its name suggests, involves exercises against resistance - this includes all forms of weightlifting like bicep curls, bench presses, and rows. When done alone as the sole intervention, resistance exercises did not show any statistically significant decrease in serum IL-6, IL-18 or CRP in any of the studies selected. Aerobic exercise on the other hand, was shown to be effective in many of the studies when performed as the sole intervention. However, the combined approach of aerobic-resistance exercise seems to confer most benefit in reducing serum levels of; in a study by Balducci $S$, when compared to a group practicing only aerobic exercises, the group practicing a combined aerobic-resistance exercise showed a $54 \%$ decrease in serum CRP compared to the former $28 \%$.

Intensity of aerobic exercise was measured in the studies via a variety of methods as discussed before. Using the American College of Sports Medicine (ACMS) classification of exercise intensity (Pollock et al. 1998), there are many ways to evaluate intensity; used in the studies selected are MHR, HRR, and $\mathrm{VO}_{2}$ max. Of the studies utilizing aerobic exercises, 6 studies were classified as of hard intensity, one study was of very hard intensity and one study was of moderate intensity. The remaining studies did not have an objective measure of exercise intensity. The limited range of differing intensities of the exercise did not allow for comparison of efficacy of certain intensity but presumably the more intense an exercise is; the more effect it would exert on the biomarkers. For the same reasons, the duration of an exercise could not be compared, as well.

\section{DISCUSSION}

We summarized the prevalence of MetS in different countries in Figure 3. Chronic low-grade inflammation is an essential part in the pathogenetic mechanism of MetS; other mechanisms include insulin resistance and neurohumoral activation (Rochlani et al. 2017). Increased visceral adiposity is posited and demonstrated as the causative aetiology that leads to most pathways involved in MetS (Matsuzawa et al. 2011) including chronic inflammation. Chronic inflammation is involved directly in promoting CVD and thus responsible for the morbidity and mortality posed by this clinical entity. Other than the effect of chronic inflammation towards the cardiovascular system, MetS was linked to other adverse effects. In one study, it was found that MetS potentiated the adverse effects of both short- and long-term exposure to air pollution (Eze et al. 2015). Our systematic review indicates that exercise 
indeed confers a beneficial effect towards the inflammatory status of the MetS patient. In this review of 11 studies consisting of 466 participants, 7 of the studies enrolled had statistically significant decrease in serum levels of the biomarkers CRP, IL-6 and IL-18. CRP and IL-6 was used more commonly in the studies. IL-18 had fewer studies testing for it, limiting the analysis that can be done on it.

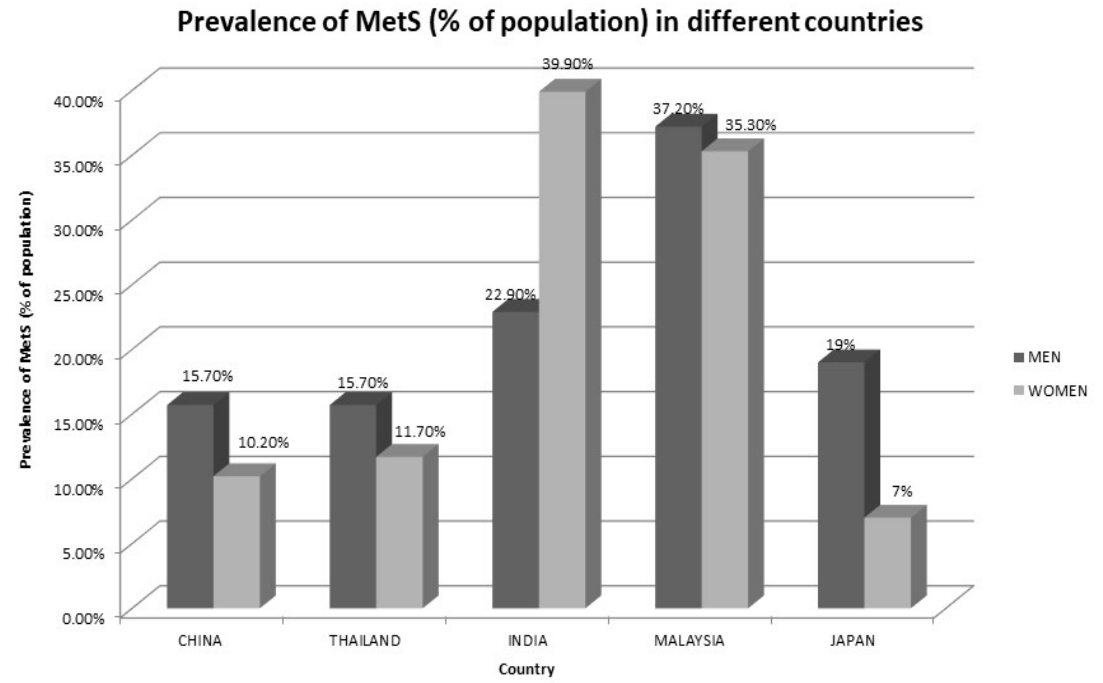

FIGURE 3. Prevalence of MetS in different countries

In terms of type of exercise, aerobic exercise may have more impact on the MetS patients compared to resistance exercises. Most of the studies enrolled into our review utilized aerobic exercises in their training regime, with only 2 studies choosing to focus solely on resistance exercises. This was probably due to tedious nature of this exercise, many requiring some form of costly equipment and meticulous supervision for proper execution of the range of motion of the exercises. Aerobic exercises are simple and require not more than a venue to perform. Where resistance exercises were utilized alone, there was no statistically significant decrease in the outcomes measured although admittedly the sample size was too small to draw a meaningful conclusion. The role of a combined aerobic-resistance training cannot be firmly concluded. When compared to a sole aerobic exercise group, combined exercise seems to bring about a greater decrease in CRP levels. Studies were done which supported the use of a combined exercise regime in type 2 diabetics, improving vascular function, peak oxygen consumption and muscle strength (Maiorana et al. 2001). Therefore, it is not surprising to summarize that a combined aerobic-resistance exercise regime could be of similar benefit in MetS patients and be of superior benefit to aerobic exercise alone. However, more studies should be done to investigate this matter.

The intensity of the exercise programs in the present systematic review was assessed using a few parameters; MHR, HRR, and $\mathrm{VO}_{2}$ max and classed accordingly using the ACSM classification of physical activity intensity. Many studies had not included a proper measure of intensity of their exercise program. Of those that were measured, most were classed as 'hard' in the ACSM's classification. This shows that the studies are in line with the ACSM's recommendation for the healthy adults. Another important factor to look at is the duration of the exercise program as well as the frequency of exercise per week. The duration of training for each session ranges from 20-60 min per 
session, in line with the ACSM's recommended duration of training for the healthy adult. Most of the studies had the participants train 3 times/week. Therefore, it can be concluded that an aerobic exercise program comprising 3 sessions/week with training duration 20-60 min would result in definite improvement in the inflammatory status of the patient.

The studies enrolled in the present systematic review did not report any adverse effects of exercise on the participants. However, the authors feel that it is important to discuss upon the possible adverse effects of implementing an exercise program in MetS patients. The risk of sudden cardiac death in MetS patients have been observed to be higher in patients with MetS, risk being higher in proportion to the number of MetS components present (Hess et al. 2017). It is well known that MetS extracts a heavy toll on the cardiovascular system; increasing the incidence of coronary heart disease and cerebrovascular accidents in patients (Alexander et al. 2003; Hunt et al. 2004; Isomaa et al. 2001). The presence of the former in MetS patients could put them at risk of sudden cardiac death when put under high intensity physical exertion. One study looking at the relationship between exercise and sudden cardiac death determined that in the habitually sedentary adults with coronary heart disease diagnosed or otherwise, rigorous physical activity may trigger an acute coronary event (Corrado et al. 2006). Thus, pre-exercise screening for coronary artery disease should be done before starting a patient on an exercise program and its intensity should not be too rigorous in the first session.

There were few limitations in this systematic review. Firstly, as systematic reviews can only be done on the studies that are available and the number of studies investigating the effects of exercise on inflammatory markers in MetS is understandably small. A larger sample size is needed to properly investigate the effects of exercise in MetS patients; future research on this topic is much needed. Secondly, none of the studies had tried to isolate and compare the individual effect of type, intensity and duration of exercise has on inflammatory markers in MetS. Therefore, the varying types, intensity of exercise, duration, and duration of intervention means that the results cannot be ascribed to one specific factor. Thirdly, this study also did not specify the results by population characteristics such as age, sex, and race. These factors may influence the outcomes measured. Admittedly, this systematic review also did not focus on the statistical analysis. Lastly, this study was also limited by the choice to only include studies written in English. Many studies which contain relevant data may have been excluded.

\section{CONCLUSION}

Exercise plays an important role in controlling the inflammatory markers in the body. The present systematic review was written in order to aid clinicians in recommending the best modalities of exercise with regard to type, duration and intensity to positively impact the clinical and laboratory parameters in patients with MetS. There are very few exercise based research conducted to date experimenting on the role of lifestyles modifications on inflammatory markers with MetS patients. More long term studies with larger sample size and wide variety of specific type, duration, and intensity of exercise should be conducted to substantiate the results presented in this systematic review. This review also aimed to attract other researchers especially in developing countries to perform further studies on exercise interventions in MetS.

\section{ACKNOWLEDGEMENTS}

The authors acknowledge the kind help received from the undergraduate Special Study Module (FF-2018-306). No funding was received for this study and therefore no conflict of interest.

\section{REFERENCES}

Alberti, K.G., Zimmet, P. \& Shaw, J. for the IDF Epidemiology Task Force Consensus Group. 2005. The metabolic syndrome--a new worldwide definition. Lancet 366(9491): P1059-1062.

Alexander, C.M., Landsman, P.B., Teutsch, S.M. \& Haffner, S.M. 2003. NCEP-defined metabolic syndrome, diabetes, and prevalence of coronary heart disease among NHANES III participants age 50 years and older. Diabetes 52(5): 1210-1214.

Bastard, J.P., Jardel, C., Delattre, J., Hainque, B., Bruckert, E. \& Oberlin, F. 1999. Evidence for a link between adipose tissue interleukin- 6 content and serum C-reactive protein concentrations in obese subjects. Circulation 99(16): 22212222.

Corrado, D., Migliore, F., Basso, C. \& Thiene, G. 2006. Exercise and the risk of sudden cardiac death. Herz Kardiovaskuläre Erkrankungen 31(6): 553-558.

Expert Panel on Detection, Evaluation, and Treatment of High Blood Cholesterol in Adults. 2001. Executive summary of the third report of the national cholesterol education program (NCEP) expert panel on detection, evaluation, and treatment of high blood cholesterol in adults (Adult Treatment Panel III). JAMA 285(19): 2486-2497.

Eze, I.C., Schaffner, E., Foraster, M., Imboden, M., von Eckardstein, A., Gerbase, M.W., Rothe, T., Rochat, T., Kunzli, 
N., Schindler, C. \& Probst-Hensch, N. 2015. Long-term exposure to ambient air pollution and metabolic syndrome in adults. PloS ONE 10(6): e0130337.

Festa, A., D’Agostino Jr. R., Howard, G., Mykkanen, L., Tracy, R.P. \& Haffner, S.M. 2000. Chronic subclinical inflammation as part of the insulin resistance syndrome: The insulin resistance atherosclerosis study (IRAS). Circulation 102(1): 42-47.

Fischer, C.P., Perstrup, L.B., Berntsen, A., Eskildsen, P. \& Pedersen, B.K. 2005. Elevated plasma interleukin-18 is a marker of insulin-resistance in type 2 diabetic and nondiabetic humans. Clinical Immunology 117(2): 152-160.

Fried, S.K., Bunkin, D.A. \& Greenberg, A.S. 1998. Omental and subcutaneous adipose tissues of obese subjects release interleukin-6: depot difference and regulation by glucocorticoid. The Journal of Clinical Endocrinology and Metabolism 83(3): 847-850.

Hess, P.L., Al-Khalidi, H.R., Friedman, D.J., Mulder, H., Kucharska-Newton, A., Rosamond, W.R., Lopes, R.D., Gersh, B.J., Mark, D.B., Curtis, L.H., Post, W.S., Prineas, R.J., Sotoodehnia, N. \& Al-Khatib, S.M. 2017. The metabolic syndrome and risk of sudden cardiac death: The atherosclerosis risk in communities study. Journal of the American Heart Association 6(8): e006103.

Hunt, K.J., Resendez, R.G., Williams, K., Haffner, S.M. \& Stern, M.P. 2004. National cholesterol education program versus world health organization metabolic syndrome in relation to all-cause and cardiovascular mortality in the San Antonio heart study. Circulation 110(10): 1251-1257.

Isomaa, B., Almgren, P., Tuomi, T., Forsen, B., Lahti, K., Nissen, M., Taskinen, M.R. \& Groop, L. 2001. Cardiovascular morbidity and mortality associated with the metabolic syndrome. Diabetes Care 24(4): 683-639.

Kaur, J. 2014. A comprehensive review on metabolic syndrome. Cardiology Research and Practice 2014: 943162.

Kim, J.H., Bachmann, R.A. \& Chen, J. 2009. Interleukin-6 and insulin resistance. Vitamins and Hormones 80: 613-633.

Maiorana, A., O’Driscoll, G., Cheetham, C., Dembo, L., Stanton, K., Goodman, C., Taylor, R. \& Green, D. 2001. The effect of combined aerobic and resistance exercise training on vascular function in type 2 diabetes. Journal of the American College of Cardiology 38(3): 860-866.

Matsuzawa, Y., Funahashi, T. \& Nakamura, T. 2011. The concept of metabolic syndrome: contribution of visceral fat accumulation and its molecular mechanism. Journal of Atherosclerosis and Thrombosis 18(8): 629-639.

Moreira, G.C., Cipullo, J.P., Ciorlia, L.A., Cesarino, C.B. \& Vilela-Martin, J.F. 2014. Prevalence of metabolic syndrome: association with risk factors and cardiovascular complications in an urban population. PloS ONE 9(9): e105056.

Pedersen, B.K. \& Fischer, C.P. 2007. Beneficial health effects of exercise--the role of IL-6 as a myokine. Trends in Pharmacological Sciences 28(4): 152-156.

Pollock, M.L., Gaesser, G.A., Butcher, J.D., Després, J.P., Dishman, R.K., Franklin, B.A. \& Garber, C.E. 1998.
ACSM position stand: The recommended quantity and quality of exercise for developing and maintaining cardiorespiratory and muscular fitness, and flexibility in healthy adults. Medicine \& Science in Sports \& Exercise 30(6): 975-991.

Rochlani, Y., Pothineni, N.V., Kovelamudi, S. \& Mehta, J.L. 2017. Metabolic syndrome: Pathophysiology, management and modulation by natural compounds. Therapeutic Advances in Cardiovascular Disease 11(8): 215-225.

Rutter, M.K., Meigs, J.B., Sullivan, L.M., D'Agostino Sr., R.B. \& Wilson, P.W. 2004. C-reactive protein, the metabolic syndrome, and prediction of cardiovascular events in the Framingham Offspring Study. Circulation 110(4): 380-385.

Srikanthan, K., Feyh, A., Visweshwar, H., Shapiro, J.I. \& Sodhi, K. 2016. Systematic review of metabolic syndrome biomarkers: a panel for early detection, management, and risk stratification in the West Virginian population. International Journal of Medical Sciences 13(1): 25-38.

Straczkowski, M., Kowalska, I., Nikolajuk, A., Otziomek, E., Adamska, A., Karolczuk-Zarachowicz, M. \& Gorska, M. 2007. Increased serum interleukin-18 concentration is associated with hypoadiponectinemia in obesity, independently of insulin resistance. International Journal of Obesity 31(2): 221-225.

Takamiya, T., Zaky, W.R., Edmundowics, D., Kadowaki, T., Ueshima, H., Kuller, L.H. \& Sekikawa, A. 2004. WHOdefined metabolic syndrome is a better predictor of coronary calcium than ATPIII criteria in American men age 40-49. Diabetes Care 27(12): 2977-2979.

Van Guilder, G.P., Hoetzer, G.L., Greiner, J.J., Stauffer, B.L. \& Desouza, C.A. 2006. Influence of metabolic syndrome on biomarkers of oxidative stress and inflammation in obese adults. Obesity 14(12): 2127-2131.

Woods, J.A., Wilund, K.R., Martin, S.A. \& Kistler, B.M. 2012. Exercise, inflammation and aging. Aging and Disease 3(1): 130-134.

Zainuddin, L.R., Isa, N., Muda, W.M. \& Mohamed, H.J. 2011. The prevalence of metabolic syndrome according to various definitions and hypertriglyceridemic-waist in Malaysian adults. International Journal of Preventive Medicine 2(4): 229-237.

Srijit Das

Department of Human \& Clinical Anatomy

College of Medicine \& Health Sciences

Sultan Qaboos University

Muscat 123

Sultanate of Oman

Isa Naina-Mohamed \& Mohamed S Zulfarina

Department of Pharmacology

Faculty of Medicine

Universiti Kebangsaan Malaysia Medical Centre

56000 Cheras, Kuala Lumpur, Federal Territory

Malaysia 
Hazwan Hazrin Salim, Azwani Zawawi, Tarrsini Thevaraj, Ku Nurmahirah Ku-Ahmad-Nasir, Dennis Kheng Zhou \& Seong Lin Teoh*

Department of Anatomy

Faculty of Medicine

Universiti Kebangsaan Malaysia Medical Centre 56000 Cheras, Kuala Lumpur, Federal Territory Malaysia
*Corresponding author; email: teohseonglin@ppukm.ukm.edu. my

Received: 27 November 2019

Accepted: 11 November 2020 